\title{
Analysis of Plantation Management Achievement Based on Sustainable Development
}

\author{
Wiwik Widiati $^{1 *}$, Aras Mulyadi ${ }^{1}$, Almasdi Syahza $^{2}$, Mubarak $^{1}$ \\ ${ }^{1}$ Department of Environmental Science, Graduate Program, University of Riau, Pekanbaru 28131, Indonesia \\ ${ }^{2}$ Faculty of Teacher Training and Education, University of Riau, Pekanbaru 28131, Indonesia
}

Corresponding Author Email: wiwik.widiati.ww@gmail.com

https://doi.org/10.18280/ijsdp.150418

Received: 22 October 2019

Accepted: 14 March 2020

\section{Keywords: \\ ISPO, RSPO, sustainable, palm oil}

\begin{abstract}
The objective of this study is to analyze sustainability achievement level of palm oil plantation management based on integration principle and criteria of ISPO and RSPO. The sustainable development on palm oil are presented through 5-dimensional these are legality of plantation business, management of plantation, management and monitoring of environment, responsibility towards workers and social responsibility and community empowerment. This study was conducted in 5 estates and 3 palm oil mill of state own company in Riau Province. The study was conducted through audit method using checklist of plantation management on sustainable development standard. Results of descriptive analysis showed that the implementation standards based on sustainable development dimensions of palm oil showed achievement level of $82.43 \%$. This achievement became a baseline for management to improve their performance which was focused on the attributes in each dimension. This study is relevant to be implemented on similar industries, due to the checklist instrument is easily adopted for assessing the plantation management achievements based on sustainable development standard.
\end{abstract}

\section{INTRODUCTION}

The biggest challenges of Indonesian palm industry at present and in the coming years are negative campaigns due to the impact of plantation expansion and growing perceptions of environmental degradation as a consequence of fertilizers and chemicals usage which have an impact on river water pollution, reduced of quantity groundwater, soil erosion and air pollution.

Sustainability of the palm oil industry is influenced by effective management to minimize or reduce negative impacts on environment, while at the same time encouraging economic growth and the implementation of CSR programs. To provide an interactions overview between aspects of sustainable development, research needs to be conducted to analyze the level of achievement of Oil Palm Plantation industry referring to the principles of sustainable development. The results this research can be utilized by management to formulate policies to meet sustainable development.

Ecological sustainability needs to be considered due to sustainability of economic and community depends on the integrity of biosphere and ecological processes in it. The emphasizing economic sustainability is improving quality of human welfare. Social sustainability includes the equal opportunity and ability of community to overcome the main problems in their lives [1].

The main challenge in developing sustainable development concept are first, global warming due to greenhouse effect. Second, degradation of land which will threaten continuity of food supply. Third, releasing of hazardous chemicals into environment that directly harms human health. Fourth, depletion of the ozone layer due to chlorine and bromine emissions caused by the production and consumption of these products. Fifth, challenges of future development are depletion of non-renewable resources, including threats to land availability due to global warming, sea level rise, soil erosion, desertification and salinization. Fresh air and clean water are becoming scarce resource due to pollution caused by harmful gas emissions and toxic chemicals usage [2].

Sustainable development concept has been adopted in oil palm plantation management by considering that this industry is as one drivers of national economy which providing benefits, and also gives impact on the environment, and surrounding communities. Refer to Diesendorf [1], the model of sustainability integrates ecological, social and economic aspects without requiring tradeoffs. It has four logical levels: ethical principles, broad goals, measurable objectives or indicators, and a broad strategy for implementation that involve government, business organizations and involving community participation and empowerment.

Indonesian Sustainable Palm Oil (ISPO) is Indonesia palm oil standards, internally is a guideline for palm oil industry actors in managing their activity to produce sustainable product and externally as a step to penetrate global market. The main objective of this standard is to produce sustainable palm oil products in order to provide competitive advantage. Roundtable on Sustainable Palm Oil, is a global sustainable palm oil standard, which adopts 3 pillars of sustainable development as outlined in the Sustainable Development Goals (SDGs), with the aim of producing and using sustainable palm oil [3].

In a long term, development of palm oil plantation towards sustainable system, not only increasing its productivity but also affect product acceptance. The implementation of principles and criteria will place Indonesia as an 
environmentally friendly of palm oil producer which consider ethics by promoting principle of sustainable development, so far growth of investation in palm oil business sector will be better and more conducive [4].

Seeing the importance of the existence of the palm oil industry in Indonesia as a provider of workforce while at the same time contributing greatly to poverty alleviation and addressing the challenges of global market, it is necessary to determine the sustainability level achievement of its management so the challenges that will hamper the development of the palm oil industry can be addressed appropriately, while also being able to answer issues that threaten its sustainability. This paper also has determined 5 dimension of sustainable palm oil which is as an integration of ISPO and RSPO principles and criteria [5]. These dimensions are land legality, plantation management, environmental management and monitoring and responsibility for workers as well as social responsibility and community empowerment.

Originality of this study is showed by the using of Sustainable Development Checklist which is developed from integration of Principles and Criteria ISPO and RSPO to asses Management Plantation Achievement. The materials and methods section provide Dimension, Attributes and Indicators of Sustainable Development. Section 2 provide materials and methods used to this study and the description about sustainable palm oil. Section 3 provide results of the study that is achievement level of each dimensions of sustainable palm oil. Section 4 provide discussion about the how to improve the achievement level and section 5 provide conclusion.

\section{MATERIALS AND METHOD}

\subsection{Sustainable palm oil}

Sustainable development concept has been adopted in oil palm plantation management by considering that this industry is as one drivers of national economy which providing benefits, and also gives impact on the environment, and surrounding communities. The model of sustainability integrates ecological, social and economic aspects without requiring tradeoffs. It has four logical levels: ethical principles, broad goals, measurable objectives or indicators, and a broad strategy for implementation, which involve government, business organizations and involving community participation and empowerment [1].

Indonesian Sustainable Palm Oil (ISPO) is Indonesia palm oil standards, internally is a guideline for palm oil industry actors in managing their activity to produce sustainable product and externally as a step to penetrate global market. The main objective of this standard is to produce sustainable palm oil products in order to provide competitive advantage. Roundtable on Sustainable Palm Oil (RSPO), is a global sustainable palm oil standard, which adopts 3 pillars of sustainable development as outlined in the Sustainable Development Goals (SDGs), with the aim of producing and using sustainable palm oil.

Table 1 shows the linkages of each principle of ISPO RSPO with 3 sustainable development pillars, similarities and differences between ISPO and RSPO. Both schemes have their specific characteristics, this is because the background of the construction of the two schemes is different [6].

The basic difference between ISPO and RSPO are, first determination of High Conservation Value area, while in ISPO the high conservation value is applied as river bank and a spring in the concession area. Second, principle of Free Prior Informed Consent in RSPO, the process of land clearing not only consider legal aspect but also requires participatory mapping by involving all affected parties and authorities. Third, principle New Planting Procedure and no primary forest conversion or area with high conservation value for new planting [6]. Table 2 shows the differences of principles and criteria ISPO - RSPO.

In long term, palm oil plantation development towards sustainable system, is increasing its productivity as well as affecting product acceptance. The implementation of principles and criteria will be placing Indonesia as a producer of environmentally friendly palm oil products which consider ethics by promoting principle of sustainable development, so far growth of investation in palm oil business sector will be better and more conducive [4].

Table 1. Similarity of principles and Criteria ISPO - RSPO

\begin{tabular}{|c|c|c|c|c|}
\hline$P$ and $C$ & ISPO & $P$ and $\mathbf{C}$ & RSPO & Pillar \\
\hline 1 & Legality of Plantation Business & 2 & Compliance with applicable laws and regulations & Social \\
\hline \multirow{2}{*}{2} & \multirow{2}{*}{ Management of Plantation } & 4 & $\begin{array}{l}\begin{array}{l}\text { Use of appropriate best practices by growers and } \\
\text { millers }\end{array} \\
\text {. }\end{array}$ & Economics \\
\hline & & 3 & $\begin{array}{c}\text { Commitment to long-term economic and financial } \\
\text { viability }\end{array}$ & Economics \\
\hline 4 & $\begin{array}{l}\text { Environment management and } \\
\text { monitoring }\end{array}$ & 5 & $\begin{array}{c}\text { Environmental responsibility and conservation of } \\
\text { natural resources and biodiversity }\end{array}$ & Environment \\
\hline 5 & Responsibility to workers & & Responsible consideration of employees, and of & Social \\
\hline 6 & $\begin{array}{l}\text { Social responsibility and } \\
\text { community empowerment }\end{array}$ & 6 & $\begin{array}{l}\text { individual and communities affected by growers and } \\
\text { mills }\end{array}$ & Economics \\
\hline 7 & $\begin{array}{l}\text { Continuous business } \\
\text { improvement }\end{array}$ & 8 & $\begin{array}{c}\text { Commitment to continuous improvement in key areas } \\
\text { of activity }\end{array}$ & $\begin{array}{l}\text { Economics, Social } \\
\text { and Environment }\end{array}$ \\
\hline
\end{tabular}

Source: ISPO (2015), RSPO (2014)

Table 2. Differences of Principles and Criteria ISPO - RSPO

\begin{tabular}{|c|c|c|c|c|}
\hline$P$ and $C$ & ISPO & $P$ and $C$ & RSPO & Pillar \\
\hline- & - & 1 & Commitment to transparency & Social \\
\hline 3 & Protection of primary natural forest and peatlands & - & - & Environment \\
\hline- & 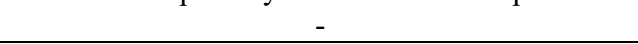 & 7 & New Planting Procedure & Social and Environment \\
\hline
\end{tabular}


Table 3. Locations of study units

\begin{tabular}{|c|c|c|c|c|c|}
\hline No & POM & SUPPLY BASE & VILLAGE & SUB DISTRICT & DISTRICT \\
\hline 1 & Tandun & $\begin{array}{c}\text { - Tandun } \\
\text { - Sei Lindai } \\
\text { - Sei Berlian }\end{array}$ & $\begin{array}{l}\text { - Talang Danto } \\
\text { - Kasikan } \\
\text { - Sinama Nenek }\end{array}$ & Tapung Hulu & Kampar \\
\hline 2 & Sei Pagar & $\begin{array}{c}\text { - Sei Pagar } \\
\text { - Small Holder } \\
-3^{\text {rd }} \text { party source }\end{array}$ & $\begin{array}{l}\text { - Pantai Raja } \\
\text { - Hang Tuah }\end{array}$ & Perhentian Raja & Kampar \\
\hline \multirow[t]{2}{*}{3} & \multirow[t]{2}{*}{ Lubuk Dalam } & \multirow[t]{2}{*}{$\begin{array}{l}\text { - Lubuk Dalam } \\
\text { - Small Holder } \\
\text { - } 3^{\text {rd }} \text { party source }\end{array}$} & $\begin{array}{c}\text { - Lubuk Dalam } \\
\text { - Sialang Baru } \\
\text { - Rawang Kao } \\
\text { - Rawang Kao Barat }\end{array}$ & Lubuk Dalam & \multirow[t]{2}{*}{ Siak Sri Indrapura } \\
\hline & & & Kuala Gasib & Koto Gasib & \\
\hline
\end{tabular}

Source: PT. Perkebunan Nusantara V

\subsection{Method}

The study was conducted at several business units of state owned enterprise plantation in District of Kampar and Siak Sri Indrapura Province of Riau that shown completely in Table 3.

The qualitative method used in this study to determine level of achievement in implementing the principle and criteria of sustainable palm oil. The numbers of units study, determined by formula as follow:

$$
0.8 \sqrt{y}
$$

y: number of plantations and palm oil mill units.

The location of units study was determined purposively, due to consideration of source (fresh fruit bunches), whether from own estates, scheme smallholders estate or from third party, as shown in Table 1.

Table 4. Dimension, attributes and indicators on sustainable development

\begin{tabular}{ccc}
\hline Sustainable Palm Oil & $\begin{array}{c}\text { Number of } \\
\text { Attribute }\end{array}$ & $\begin{array}{c}\text { Number of } \\
\text { Indicators }\end{array}$ \\
\hline $\begin{array}{c}\text { Dimension 1, } \\
\text { Legality of Plantation Business } \\
\text { Dimension 2, }\end{array}$ & 9 & 31 \\
$\begin{array}{c}\text { Management Plantation } \\
\text { Dimension 3, }\end{array}$ & 8 & 77 \\
Environment Management and \\
$\quad \begin{array}{l}\text { Monitoring } \\
\text { Dimension 4, }\end{array}$ & 11 & 46 \\
$\begin{array}{c}\text { Responsibility to Worker } \\
\text { Dimension 5, } \\
\text { Social responsibility and } \\
\text { community empowerment } \\
\text { TOTAL }\end{array}$ & 6 & 39 \\
\hline Source: Interpreted from PandC ISPO (2015) [7] & $\mathbf{4 0}$ & $\mathbf{2 1 2}$ \\
\hline
\end{tabular}

In search of primary data by audit process, a checklist of Sustainable Development Principles of Plantation Management was developed and discussed with internal auditor's team of the company some of fellow auditors, to ensure that all indicators in the ISPO and RSPO standards are covered. Primary data was also collected during field observations, supplier interviews, cooperative manager, labor union, management representatives, and committees of gender, surrounding community leaders. Secondary data was obtained by contacting person in charge in company, and type data collected are statement areas, estates activities, production of FFB, CPO, and kernels, audit report, annual report, management report, environmental monitoring report, licenses and other data related.

There are 5 dimensions were set up in this study to elaborate Sustainable Development in palm oil plantation management. Dimensions were interpreted as principles in ISPO-RSPO, which is fundamental statements about desired outcome. Each dimension consists of several attributes or criteria that is variable to measure its implementation. Each attribute consists of several indicator, as variable to be measured during audit. Distribution of dimensions, attribute and indicators shown on Table 4.

Analysis was carried out by giving score on performance of each indicator from audit results. The achievement percentage of each dimension was obtained by adding up total score on each indicator in its each attribute divided by the total score of dimensions. Scoring to assess indicators performance shown at Table 5.

Table 5. Scoring of indicator performance based on audit result

\begin{tabular}{|c|c|c|}
\hline Score & Criteria & Remarks \\
\hline 0 & Non Comply & $\begin{array}{c}\text { Not appropriate with laws and } \\
\text { regulations }\end{array}$ \\
\hline 1 & On Progress & $\begin{array}{l}\text { Not appropriate but can be } \\
\text { completed in } 90 \text { days }\end{array}$ \\
\hline 2 & Comply & $\begin{array}{c}\text { Appropriate with laws and } \\
\text { regulations }\end{array}$ \\
\hline
\end{tabular}

\section{RESULTS}

This section provides level of management achievement in implementing principles and criteria sustainable palm oil. The results of this study will be willing the basis for improving each dimension of sustainability performance.

\subsection{Dimension 1, legality of plantation}

Legality of Plantation Dimensions, consist of 9 attributes and 31 indicators, with maximum total score is 62 . Based on scoring to audit results, achievement of each unit study shown in Table 6. The Average achievement level of corporate is $85.48 \%$. Study of ISPO implementation at East Kalimantan indicate that in Principles 1 Licensing of system showed that the level of achievement was $82.22 \%$ [8], as well as [9] study in West Java showed lower performance that is $77.8 \%$.

The challenge to increase performance of Dimension 1 is in completion licensing documents, due to government service system and requirements needed to complete the permit. 
Differences in service systems and types of requirements have an impact on the time needed to obtain a permit, so this indicator is relatively difficult to set a time for completion [8].

The indicator that caused the failure to fulfill the Attribute 6 Location of Estate is because the research location unit cannot prove the suitability of the location of the activity site to the provincial spatial plan, even though it already has a Cultivation Right (HGU). This is due to the unavailability of maps of the suitability of the location of the plantation to the spatial layout of Riau Province.

Research conducted by Wahyuni et al. [10] shows that the obstacle in carrying out the revised The Spatial Plan of Riau province was due to conflicts between the actors involved in the ratification process. The Ministry of Environment and Forestry (KLHK) and the Regional Government of Riau Province have the most powerful roles, besides the emergence of the role of the Ombudsman, private (companies), and nongovernmental organizations (NGOs) in the contestation revision of Riau Province Spatial Plan.

Performance level of Dimension 1 can be improved by the program which is directly related to Attributes 1 Permit of location, Attributes 3 acquisition of Land for Right, Attributes 6 Location of Estates, Attributes 8 Land Dispute and Attributes 9 Legal entity. The programs are focused on improving the performance of indicators that can be traced from the results of the audit. Issuance of land certificates and legal certainty on the use of concession area. Suitability of land concessions with spatial plans will provide legal certainty in terms of ownership or control and management of the area or area used as a plantation business [11].

Constraints on the issuance of spatial maps be the cause of companies to display the suitability of their plantation areal to the spatial maps. Research conducted showed that the obstacle in implementing the revised Regional Spatial Planning of Riau Province is due to inter-actor conflict involved in ratification process. The role of the Regional Spatial Planning of Riau Province is important to ensure that no deforestation issues can be fulfilled by company, according to the sustainable palm oil standards required that Fresh Fruit Bunches is not produced from primary forest.

Mechanism for resolving land disputes which was set up by units study is still not in accordance with standards requirement, namely the of an absence of disputed land maps presented in a participatory manner and evidence of a settlement mechanism agreed by the parties [4, 12, 13]. Unresolved of disputed land will give an impact on the polarization of all parties and become obstacles in producing sustainable palm oil.

Mechanism for ascertaining and setting completion steps in order to comply with relevant laws, policies and regulations, is one of fulfilling better corporate governance requirements. Performance level of Dimension 1 can be improved by the program which is directly related to Attributes 1 Permit of location, Attributes 3 Land Right, Attributes 6 Location of Estates, Attributes 8 Land Dispute and Attributes 9 Legal entity. The programs are focused on improving the performance of indicators that can be traced from audit results.

Table 6. Percentage achievement on dimension 1, legality of plantation

\begin{tabular}{|c|c|c|c|c|c|c|c|c|}
\hline \multirow[t]{2}{*}{ No } & \multirow[t]{2}{*}{ Attributes } & \multirow{2}{*}{$\begin{array}{l}\text { Number of } \\
\text { Indicators }\end{array}$} & \multicolumn{3}{|c|}{$\begin{array}{c}\text { Score from Audit Result } \\
\text { for Each Study Units }\end{array}$} & \multirow[t]{2}{*}{ Average } & \multirow[t]{2}{*}{$\begin{array}{c}\text { Percentage of } \\
\text { Average (\%) }\end{array}$} & \multirow[t]{2}{*}{$\begin{array}{c}\text { Maximum } \\
\text { Score }\end{array}$} \\
\hline & & & 1 & 2 & 3 & & & \\
\hline 1 & Permit of Location & 6 & 10 & 10 & 10 & 10 & 83.3 & 12 \\
\hline 2 & Plantation must have related permits & 2 & 4 & 4 & 4 & 4 & 100 & 4 \\
\hline 3 & Acquisition of Land for Plantation & 2 & 3 & 4 & 4 & 3.7 & 93 & 4 \\
\hline 4 & Land Right & 2 & 3 & 4 & 3 & 3.3 & 82.5 & 4 \\
\hline 5 & $\begin{array}{l}\text { Development Estates Facilities for } \\
\text { Surrounding Community }\end{array}$ & 3 & 6 & 6 & 6 & 6 & 100 & 6 \\
\hline 6 & Location of Estate & 2 & 3 & 3 & 3 & 3 & 75 & 4 \\
\hline 7 & Neglected Land & 2 & 4 & 4 & 4 & 4 & 100 & 4 \\
\hline 8 & Land Dispute & 5 & 9 & 9 & 9 & 9 & 90 & 10 \\
\hline \multirow[t]{2}{*}{9} & Legal Entity & 7 & 10 & 10 & 10 & 10 & 71.4 & 14 \\
\hline & $\begin{array}{l}\text { TOTAL } \\
\text { Percentage of Achievemen }\end{array}$ & 31 & $\begin{array}{c}52 \\
83.87\end{array}$ & $\begin{array}{c}54 \\
87.10\end{array}$ & $\begin{array}{c}53 \\
85.48\end{array}$ & $\begin{array}{c}53 \\
85.48\end{array}$ & & $\begin{array}{c}62 \\
100\end{array}$ \\
\hline
\end{tabular}

Source: Primary Data (2018)

Note: 1. Tandun POM and Tandun, Sei Lindai, Sei Berlian Estates;2. Sei Pagar POM and Estates; 3. Lubuk Dalam POM and Estates

\subsection{Dimension 2, management of plantation}

Dimension 2 Management of Plantation consist of 8 attributes and 56 indicators, maximum total score is 132 as shown at Table 7 . Based on scoring to audit the result of each study unit's level of dimension 2 was $78.03 \%$ at Tandun, $81.06 \%$ at Sei Pagar and $78.79 \%$ at Lubuk Dalam, with average for corporate achievement level is $79.24 \%$. Study conducted by Rusli et al. [8] in this dimension shows an achievement rate of $72.88 \%$ lower and by Fuadah and Ernah [9] was $93.3 \%$ higher.

The leadership of units study is responsible for delivering company's vision and mission to all employees. Vision and mission for the organization can serve as an effort to get support from their employees to reach out company's strategic plan and performance [13].
The socialization of its vision and mission needs to be held routinely. Employees understanding of Government regulations, market, industry trends, available sustainability standards, climate change impacts, stakeholder demands, and technology development are external factors that influence company's decision to implement best management practices. Governments influence how sectors interact, compliance with government regulations is required for any company in doing business. Markets, encompassing buyers, customers, and sustainability standards often complement one another in creating incentives and providing guidelines for companies to implement certain best management [14].

Technical application of processing and yield cultivation attributes require documentation of standard operating procedures in the activities. ISO 9001: 2015 is a Quality Management System as basis for organizations to demonstrate 
their ability to provide products that meet and enhance customer satisfaction consistently through implementing and improving systems and product compatibility to meet customer requirements, applicable laws and regulations. Review every 5 years is needed to evaluate its suitability with operational activities. The adoption of best management practices will boost results, and the success of their application depends on the commitment of senior management to provide adequate direction and budget and resources [15].

Another challenges in producing sustainable palm oil is in pesticides usage, for crop maintenance due to consideration of effectiveness and efficiency, needs to be synergized with biological control techniques to optimize natural enemies role to control herbivorous populations and combining with vegetation diversity by non-cultivation planting to obtain productivity of land optimally and sustainable [16].

The impact pesticides application for spray operators needs to be monitored continuously through medical examination program, increasing awareness and discipline of personal safety equipment usage while working. Providing sufficient training to spray operators related to understanding of chemical characteristics, managing storage of materials, areas that need to be avoided from spraying activities and managing pesticide packaging waste as an effort to protect environment as well as creating a safe work environment for operators. The knowledge and practice of pesticide usage among smallholders shows that in practice of handling pesticides farmers' knowledge still needs to be improved to ensure safety and avoiding occupational hazard as one of sustainable agricultural practices requirements.

Preparation, implementation and evaluation programs of water source and quality conservation and their evaluation need to be held to ensure that consume and management of water does not affect to local communities, workers and their families. To protect ground and surface water from contamination by erosion, leaching nutrients or chemicals Minister of Environment Regulation No. 5 of 2011 Appendix II has established water conservation criteria through PROPER, these are first reclaiming by processing waste water and reused it with criteria of quality according to applicable regulatory, second recycling by using treated waste water and returned to the production process, third is the utilization of treated wastewater for other activities such as irrigation and improved system performance and fourth is preventing water loss due to leakage, or repairing system to reduce water lost.

Management policy on information to reveal an access information to stakeholders need to be developed, selective disclosure of information can be useful to foster trust, accountability in the company. Information that company done will foster a natural exchange of information to enable companies and stakeholders to make better policies. Availability list of relevant and up-to-date stakeholders is needed to create effective communication in decision making process. Stakeholder analysis can help frame problems that can be solved technically feasible, and can be politically acceptable to advance common good [17]. The decision making process should be held in a participatory, consensusoriented, accountable, transparent, responsive, fair and inclusive, effective, efficient and comply with regulations to develop good governance system. Transparency is important to foster stakeholder confidence, this situation will influence stake holder's perception to organization.

Mitigation of greenhouse gas emissions need to be developed continuously both through reducing sources and increasing carbon sequestration. The source of greenhouse gas emissions from the palm oil industry first from activities related to the use of fossil fuels for internal transportation and machinery; second from fertilizers usage; third fossil fuel consumption; fourth from the wastewater treatment process [18].

Table 7. Percentage achievement on dimension 2, management of plantation

\begin{tabular}{|c|c|c|c|c|c|c|c|c|}
\hline \multirow[t]{2}{*}{ No } & \multirow[t]{2}{*}{ Attributes } & \multirow{2}{*}{$\begin{array}{l}\text { Number of } \\
\text { Indicators }\end{array}$} & \multicolumn{3}{|c|}{$\begin{array}{l}\text { Score from Audit Result } \\
\text { for Each Study Units }\end{array}$} & \multirow[t]{2}{*}{ Average } & \multirow{2}{*}{$\begin{array}{l}\text { Percentage of } \\
\text { Average (\%) }\end{array}$} & \multirow{2}{*}{$\begin{array}{c}\text { Maximum } \\
\text { Score }\end{array}$} \\
\hline & & & 1 & 2 & 3 & & & \\
\hline 1 & $\begin{array}{l}\text { Planning to Produce Sustainable Palm Oil } \\
\text { in Short, Medium and Long term }\end{array}$ & 6 & 8 & 8 & 8 & 8 & 66.7 & 12 \\
\hline 2 & $\begin{array}{l}\text { Technical Application for Cultivating and } \\
\text { Processing }\end{array}$ & 5 & 6 & 6 & 6 & 6 & 60 & 10 \\
\hline 3 & Good Agricultural Practice & 27 & 46 & 47 & 46 & 46.3 & 85.7 & 54 \\
\hline 4 & Good Manufacturer Practices & 16 & 27 & 28 & 26 & 27 & 84.3 & 32 \\
\hline 5 & Overlapping with Mining & 1 & 2 & 2 & 2 & 2 & 100 & 2 \\
\hline 6 & Plan and Realization Development & 1 & 2 & 2 & 2 & 2 & 100 & 2 \\
\hline 7 & Providing of Information & 3 & 4 & 5 & 4 & 4.3 & 71.6 & 6 \\
\hline \multirow[t]{3}{*}{8} & Continual Improvement & 7 & 8 & 9 & 10 & 9 & 64.3 & 14 \\
\hline & TOTAL & 56 & 103 & 107 & 104 & 104.6 & & 112 \\
\hline & Percentage of Achievement (\%) & & 78.03 & 81.06 & 78.79 & 79.24 & & 100 \\
\hline
\end{tabular}

Source: Primary Data (2018)

Note: 1. Tandun POM and Tandun, Sei Lindai, Sei Berlian Estates; 2. Sei Pagar POM and Estates; 3. Lubuk Dalam POM and Estates

The efficiency of water, pesticides, chemical, fossil fuels, optimizing utilization of organic waste, reducing greenhouse gas emissions are programs that can be proposed to increase achievement level of attributes 8. Continual Improvement must become permanent goal of the organization with its main benefits is improving its performance excellence that comes from increasing organizational expertise, aligning of strategic improvement at all levels with objectives and flexibility to react immediately to opportunities that may arise ISO 9001: 2015 .

\subsection{Dimension 3, environmental management and monitoring}

Dimension 3 consists of 11 attributes and 46 indicators, with a maximum total score of 84 (Table 8 ). Protection of Primary Forests and New Plantations cannot be applied at units study, due to plantation operations have begun in 1982 and the existence of cultivated plants in each estates come from replanting process. Based on scoring to audit the result of each study unit's level of dimension 3 was $82.43 \%$ at Tandun, 
$83.78 \%$ at Sei Pagar and $82.43 \%$ at Lubuk Dalam, with average for corporate achievement level is $82.84 \%$.

The purpose of the indicators in this dimension is to preserve, protect and enhance ecosystem to provide next generation. Referring to the ISPO Principles and Criteria [6] research conducted by Rusli et al. [8] on the Principles of Environmental Management and Monitoring showed the achievement level are 54.69\% and by Fuadah and Ernah [9] are $100 \%$. The difference in this level due to several indicators added from principle and criteria of ref. [7]. Referring to RSPO Theory of Change 2018 the planet as affected area is an ecosystem service provider that needs to be protected, restored and strengthened, through the way of consumption, production and sustainable management of natural resources by stopping degradation, loss of biodiversity, controlling air and water pollution to reduce greenhouse gas emissions.

Attribute 6: Conservation of Biodiversity is $80 \%$ and attribute 8 for Protected Areas is $75 \%$. The protected area identified in the research unit is the local protected area in the form of a river border and the remaining forest. The role of the local protected area is to maintain the presence of the remaining plants and wildlife. Based on a biodiversity perspective, areas in the form of remaining forest have higher plant diversity values than river borders, and wildlife diversity is almost uniform both in forested areas, river borders, and oil palm plantations [12].

Achievement of attribute 9 conservation of areas with erosion potential is $83.3 \%$. Based on field observations, most of the cover crops were oil palm and shrubs (litter and nuts). Generally, the effect of plants on erosion is to prevent rainwater from falling directly on the surface of the soil, inhibit surface runoff and absorption of surface water into the soil is strengthened by transpiration through vegetation. Roots improve soil stability by increasing soil strength, granularity and porosity. Biological activities related to plant growth also have a positive impact on soil porosity so that permeability increases and reduces erosion rates. Generally, erosion prevention efforts are carried out by making traditional terraces and planting cover crops as well as for oil palm plants with a heap of midrib. These efforts can reduce the sensitivity of the soil to erosion [19].

To encourage this dimension some of the efforts that need to be done include:

Improving of wastewater and processing water management, through the re-identification of all sources and monitoring of waste water point according to the regulation of Minister of Environment of Republic of Indonesia No. 5/ 2011 about PROPER.

Table 8. Percentage achievement on dimension 3, environmental management and monitoring

\begin{tabular}{|c|c|c|c|c|c|c|c|c|}
\hline \multirow[t]{2}{*}{ No } & \multirow[t]{2}{*}{ Attributes } & \multirow{2}{*}{$\begin{array}{l}\text { Number of } \\
\text { Indicators }\end{array}$} & \multicolumn{3}{|c|}{$\begin{array}{l}\text { Score from Audit Result } \\
\text { for Each Study Units }\end{array}$} & \multirow[t]{2}{*}{ Average } & \multirow{2}{*}{$\begin{array}{l}\text { Percentage of } \\
\text { Average (\%) }\end{array}$} & \multirow{2}{*}{$\begin{array}{l}\text { Maximum } \\
\text { Score }\end{array}$} \\
\hline & & & 1 & 2 & 3 & & & \\
\hline 1 & $\begin{array}{c}\text { Obligation of Plantation Integrated with Palm } \\
\text { Oil Mill Unit }\end{array}$ & 3 & 5 & 6 & 5 & 5.3 & 88.9 & 6 \\
\hline 2 & Obligation Related to Environment permits & 4 & 7 & 7 & 7 & 7 & 87.5 & 8 \\
\hline 3 & Management of Hazardous Waste and Toxic & 6 & 10 & 10 & 10 & 10 & 83.3 & 12 \\
\hline 4 & Stationery Source Disruption & 3 & 5 & 5 & 5 & 5 & 83.3 & 6 \\
\hline 5 & Fire Prevention and Management & 5 & 9 & 9 & 9 & 9 & 90 & 10 \\
\hline 6 & Biodiversity Conservation & 5 & 8 & 8 & 8 & 8 & 80 & 10 \\
\hline 7 & Conservation of Water Resources and Quality & 3 & 5 & 5 & 5 & 5 & 83.3 & 6 \\
\hline 8 & Protected Area & 2 & 3 & 3 & 3 & 3 & 75 & 4 \\
\hline 9 & Conservation of High Erosion Potential & 3 & 5 & 5 & 5 & 5 & 83.3 & 6 \\
\hline 10 & Green House Gas Mitigation & 3 & 4 & 4 & 4 & 4 & 75 & 6 \\
\hline \multirow[t]{2}{*}{11} & $\begin{array}{c}\text { Protection Primary Forests and New Planting } \\
\text { Procedure }\end{array}$ & 9 & N/A & N/A & N/A & - & - & - \\
\hline & $\begin{array}{l}\text { TOTAL } \\
\text { Percentage of Achievement (\%) }\end{array}$ & 46 & $\begin{array}{c}61 \\
82.43\end{array}$ & $\begin{array}{c}62 \\
83.78\end{array}$ & $\begin{array}{c}61 \\
82.43\end{array}$ & $\begin{array}{c}61,3 \\
82.84\end{array}$ & & $\begin{array}{c}74 \\
100\end{array}$ \\
\hline
\end{tabular}

Source: Primary Data (2018)

Note: 1. Tandun POM and Tandun, Sei Lindai, Sei Berlian Estates; 2. Sei Pagar POM and Estates; 3. Lubuk Dalam POM and Estates.

Mechanism to review Environmental Management Efforts periodically, at least two years to meet the principles of 5.1.3 [7]. Its objective is to assess the effectiveness of the environmental management efforts that have been undertaken. Decree of the Minister of Environment No. 45 year 2005 about the guidelines on drafting the implementation of the Environmental Management Plan (RKL) and Environmental monitoring Plan (RPL) only requires analysis of monitoring results to measures the level of compliance, tendencies and critical points to ensure that environmental management efforts have been effectively implemented, not to review Environmental Management Plan (RPL) due to this document has been authorized and the amendment need to be consulted by environmental agency.

The implementation of training to the management officers need to become a routine agenda to ensure that all workers understand the management of waste toxic materials Hazardous (B3) to meet government regulation of the
Republic of Indonesia number 101 Years 2014 on waste management of hazardous and toxic substances.

Evaluation results of emissions monitoring on immovable source need to be done to meet the decree of Minister of Health Republic of Indonesia number 1405 year 2002 on requirements of health of work and industrial environment [20]. This indicator aims to be aimed at environmental sustainability in order to benefit the human life and other living creatures so as not to interfere with human health, other creatures and the environment caused by noise, Vibration and odor resulting from production activities.

Completeness and availability of facilities and infrastructure of firefighting need to be completed continuously to fulfill regulation Minister of Agriculture number $05 /$ Permentan/KB. 410/1/2018 concerning the opening and/or processing of plantation land without burning appendix $\mathrm{V}$ (minimum number of equipment for one core squad). 
Conservation of biodiversity and protected areas need to be enhanced to preserve the remaining of protected plants and animals. According to High conservation Value document indicates that within the plantation area has been identified species that remain in protected area and has been determined that its status is protected, rare, threatened and extinction. The socialization of preserving of protected areas to employees and surrounding communities should be held routinely in order to improve their understanding and awareness. Managing and monitoring of all identified water inside the estates that could potentially cause.

\subsection{Dimension 4, responsibility to the worker}

Based on scoring to audit the result of each study unit's level of dimension 4 was $80.77 \%$ at Tandun, $76.92 \%$ at Sei Pagar and 80.77 at Lubuk Dalam, with average for corporate achievement level is $79.49 \%$. Study conducted by Rusli et al. [8] in this dimension shows an achievement rate of $74.17 \%$ as shown in Table 9.

To encourage this dimension, every change in management leadership in unit study must be followed immediately by adjustment in organizational structure of the Occupational Safety and Health Committee (P2K3) to meet the Minister of Manpower Regulation No. Per-04 / MEN / 1987 concerning the Committee for Guidance for Occupational Safety and Health (P2K3). Management support is needed so that the P2K3 Organization can run effectively. Review of the hazard identification matrix as a form of application of risk management in the implementation of occupational health and safety. Updates are needed to ensure compliance with implementation in work activities and risk control measures [21].

Routine medical checkup on workers with occupational risks should be carried out according to the specified time period, at least once a year to maintain worker health status and assess the effect of work on health, as well as to meet Minister of Manpower and Transmigration Regulation No.Per.03 /Men/1982 regarding the obligations management to conduct medical checkup for their worker.

The percentage of attainment of Attribute 3 regarding the implementation of contract workers in companies in all study locations is $50 \%$. Wahyuni et al. [22] suggest that the model of professional outsourcing that upholds ethical and moral values and is oriented to partnership is a beneficial solution for workers.

Discipline in putting on Personal safety equipment (PPE) should be enforced to workers as well as training, to improve their awareness to occupational hazards and health problems to meet Regulation of Manpower and Transmigration Minister No. Per.08 / Men / VII / 2010 concerning Personal Protective Equipment). Research conducted by Zahara et al. [23] regarding Compliance Using Personal Protective Equipment (PPE) In terms of Knowledge and Behavior at the Hospital Infrastructure Maintenance and Maintenance Officer (IPSRS) shows a correlation between compliance using Personal Protective Equipment, knowledge and behavior.

Table 9. Percentage achievement on dimension 4, responsibility to the worker

\begin{tabular}{|c|c|c|c|c|c|c|c|c|}
\hline \multirow[t]{2}{*}{ No } & \multirow[t]{2}{*}{ Attributes } & \multirow[t]{2}{*}{$\begin{array}{l}\text { Number of } \\
\text { Indicators }\end{array}$} & \multicolumn{3}{|c|}{$\begin{array}{l}\text { Score from Audit Result for } \\
\text { Each Study Units }\end{array}$} & \multirow[t]{2}{*}{ Average } & \multirow[t]{2}{*}{$\begin{array}{l}\text { Percentage of } \\
\text { Average }(\%)\end{array}$} & \multirow[t]{2}{*}{$\begin{array}{l}\text { Maximum } \\
\text { Score }\end{array}$} \\
\hline & & & 1 & 2 & 3 & & & \\
\hline 1 & Occupational Safety and Health (K3) & 14 & 19 & 20 & 19 & 19.3 & 69.1 & 28 \\
\hline 2 & $\begin{array}{c}\text { Welfare and Improvement Workers } \\
\text { Capability }\end{array}$ & 8 & 14 & 15 & 14 & 14.3 & 89.68 & 16 \\
\hline 3 & Management of Contract Workers & 4 & 4 & 4. & 4 & 4 & 50 & 8 \\
\hline 4 & $\begin{array}{l}\text { Child Labor and Worker } \\
\text { Discrimination }\end{array}$ & 6 & 12 & 11 & 12 & 11.7 & 97.2 & 12 \\
\hline 5 & Facility of Worker Union Formation & 3 & 6 & 6 & 6 & 6 & 100 & 6 \\
\hline 6 & $\begin{array}{c}\text { Formation of Worker Cooperation } \\
\text { TOTAL } \\
\text { Percentage of Achievemen }\end{array}$ & $\begin{array}{c}4 \\
39\end{array}$ & $\begin{array}{c}8 \\
63 \\
80.77\end{array}$ & $\begin{array}{c}8 \\
60 \\
76.92\end{array}$ & $\begin{array}{c}8 \\
63 \\
80.77\end{array}$ & $\begin{array}{c}8 \\
62 \\
79.49\end{array}$ & 100 & $\begin{array}{c}8 \\
78 \\
100\end{array}$ \\
\hline
\end{tabular}

Source: Primary Data (2018)

Note: 1. Tandun POM and Tandun, Sei Lindai, Sei Berlian Estates; 2. Sei Pagar POM and Estates; 3. Lubuk Dalam POM and Estates.

\subsection{Dimension 5, social responsibility and community economic empowerment}

This dimension consists of 6 attributes and 19 indicators, with a maximum total score of 38 as shown at Table 10 . Attributes with achievement level 100\% are number 2 and 3 . Based on scoring to audit the result of each study unit's level of dimension 5 was $86.84 \%$ at Tandun, $86.84 \%$ at Sei Pagar and $91.58 \%$ at Lubuk Dalam, with average for corporate achievement level is $85.09 \%$.

Study conducted by Rusli et al. [8] in this dimension shows an achievement rate of $100 \%$. The difference is due to the indicators added into the attributes. In this study the indicators for each attribute are an integration of the ISPO Principles and Criteria 2015 and ref. [7], namely by adding indicators of participatory identification of social impacts, management plans and monitoring.

Assessment of this dimension are useful to figure out performance and increasing confidence in palm oil for products consumed. To encourage the level of achievement in this dimension 5, an open and transparent method for communication, consultation with local communities and affected parties is needed to meet transparency principle. The purpose of this attribute is to encourage the growth of province behavior based on trust and transparency with the parties to ensure a close and healthy [23].

Units study success depends on their management to develop support and manage stakeholder's expectations. Management of stakeholders can have a substantial and direct impact. The satisfaction of stakeholders can contribute significantly to the success of company. Stakeholders are dynamic, therefore identification and mechanisms need to be established to identify and update the parties that directly or indirectly have interest in units study or are affected by the activity, at least once every 6 months.

Management needs to establish a mechanism to deal with 
complaints from internal and external stakeholders of the company and socialize it. A mutually agreed mechanism for dealing with complaints, which is applied and accepted by all parties affected, is a Principle required by ref. [20]. The purpose of this mechanism in the context of palm oil sustainability based on the principle of sustainable development is to ensure business practices are carried out ethically, healthily and with integrity, and to ensure the practice of transparency and disclosure of information that is particularly relevant in the reporting of violations by employees and management, to improve the performance of attribute 6 . The percentage of achievement of attribute 6 is $62.6 \%$, to increase the percentage of achievements in this attribute management needs to establish a mechanism to deal with complaints from internal and external stakeholders of the company and to socialize it [24].

Stakeholder analysis is needed to determine the priorities of the community or community groups needed and the extent to which implementation of development programs / activities is beneficial to them. Stakeholder analysis includes several aspects, namely: 1) the stakeholders themselves (individuals or groups who have or are affected by implementation of agricultural development programs/activities), 2) participation, and 3 ) linkages as a form of participation that is more than just consultation [25].

\subsection{Achievement level of plantation management based on the sustainable development principles}

The overall level of achievement of plantation management based on sustainable development principles is $82.43 \%$, with details of the achievements in each dimension presented in Table 11

Table 10. Percentage achievement on dimension 5, social responsibility and community economic empowerment

\begin{tabular}{|c|c|c|c|c|c|c|c|c|}
\hline \multirow[t]{2}{*}{ No } & \multirow[t]{2}{*}{ Attributes } & \multirow{2}{*}{$\begin{array}{l}\text { Number of } \\
\text { Indicators }\end{array}$} & \multicolumn{3}{|c|}{$\begin{array}{l}\text { Score from Audit Result } \\
\text { for Each Study Units }\end{array}$} & \multirow[t]{2}{*}{ Average } & \multirow{2}{*}{$\begin{array}{l}\text { Percentage of } \\
\text { Average (\%) }\end{array}$} & \multirow{2}{*}{$\begin{array}{l}\text { Maximum } \\
\text { Score }\end{array}$} \\
\hline & & & 1 & 2 & 3 & & & \\
\hline 1 & $\begin{array}{l}\text { Participatory Identification of Social } \\
\text { Impacts Management Plan and } \\
\text { Monitoring }\end{array}$ & 4 & 8 & 7 & 8 & 7.67 & 95.8 & 8 \\
\hline 2 & $\begin{array}{l}\text { Environment and Social Responsibility in } \\
\text { Community }\end{array}$ & 3 & 6 & 6 & 6 & 6 & 100 & 6 \\
\hline 3 & Empowerment of Indigenous People & 4 & 8 & 8 & 8 & 8 & 100 & 8 \\
\hline 4 & $\begin{array}{l}\text { Local Business Development } \\
\text { Open and Transparent Method for }\end{array}$ & 2 & 4 & 4 & 3 & 3.67 & 91.67 & 4 \\
\hline 5 & $\begin{array}{l}\text { Communication, Consultation, with Local } \\
\text { Community and Affected Parties }\end{array}$ & 2 & 2 & 2 & 2 & 2 & 50 & 4 \\
\hline 6 & $\begin{array}{l}\text { Mutually Agreed System for Dealing } \\
\text { with Complaint, which is Implemented } \\
\text { and Accepted by all Parties Affected }\end{array}$ & 4 & 5 & 6 & 4 & 5 & 62.6 & 8 \\
\hline & $\begin{array}{l}\text { TOTAL } \\
\text { Percentage of Achievement }(\%)\end{array}$ & 19 & $\begin{array}{c}33 \\
86.84\end{array}$ & $\begin{array}{c}33 \\
86.84\end{array}$ & $\begin{array}{c}31 \\
81.58\end{array}$ & $\begin{array}{l}32.33 \\
85.09\end{array}$ & & $\begin{array}{c}38 \\
100\end{array}$ \\
\hline
\end{tabular}

Source: Primary Data (2018)

Note: 1. Tandun POM and Tandun, Sei Lindai, Sei Berlian Estates; 2. Sei Pagar POM and Estates; 3. Lubuk Dalam POM and Estates.

Table 11. Achievement level of plantation management on sustainable development

\begin{tabular}{|c|c|c|c|c|}
\hline Dimensions & TAN & LDA & SPA & AVERAGE \\
\hline Legality of Estates & 83.87 & 87.10 & 85.48 & 85.48 \\
\hline Management of Plantation & 78.03 & 81.06 & 78.79 & 79.24 \\
\hline Environmental Management and Monitoring & 82.43 & 83.78 & 82.43 & 82.84 \\
\hline Responsibility to The Worker & 80.77 & 76.92 & 80.77 & 79.49 \\
\hline Social Responsibility and Community Economic Empowerment & 86.84 & 86.84 & 81.58 & 85.11 \\
\hline$\%$ Achievement & 82.39 & 83.14 & 81.81 & 82.43 \\
\hline
\end{tabular}

Source: Primary data (2018)

\section{DISCUSSION}

In all locations of study, during audit process, same situations were found in delivering evidences needed to fulfill indicator required. Personnel provided by management as assistants during audit do not fully understand the standard requirements. Units of study have set up structure organization which is ad-hoc to implement all principles and criteria sustainable palm oil at the field. The sustainability subdivision at head office is responsible for fostering and improve awareness and standards understanding. The lack of understanding of the principles and criteria applied also provided non-requite evidence that was required in the criteria

During data collection through an audit process, we found some obstacles in the speed of supply and completeness of documentation which sometimes requires a long time in completing the data needed to complete or answer the required indicators. It caused by the lack of human resources prepared to handle and oversee the implementation of standards. Therefore, it is necessary to increase the workforce that is seconded to the fulfillment of sustainability to provide data and accelerate the fulfillment of data that is lacking. Some other obstacles are as follow: lack of understanding of the standards applied causes the auditee to not understand the procedures that must be met and required by the standard. The incidence of recurring findings caused by ineffectively corrective actions, which is not in accordance with the root of the problem. Understanding of high conservation value areas, 
so that it becomes an obstacle in managing and monitoring. Lack of understanding of greenhouse gas emissions and sources of emissions, setting up of mitigation programs for target emission reduction and monitoring efforts and understanding of sustainable palm oil standards especially for activities related to new plantings gas emissions, these will lead to the success of industry to reduce greenhouse gas.

\section{CONCLUSION}

The achievement level of management based on sustainable development principle at the company is $83.63 \%$. This achievement will become a baseline for management to improve their performance by focusing on the attributes in each dimension that still do not meet the required standards the implementation of principle and criteria in Sustainable palm oil is a continually developing issue that is linked to the involvement of various parties with their respective issues. The implementation of standards will continue to develop to ensure the sustainability of products in the local, regional and global markets. This study is based on the application of the ISPO and RSPO standards that were integrated as a starting point for the study. The analysis results show that the level of achievement in various units shows relatively the same percentage of performance in both core palm oil and third parties with the level of non-compliance with the required standards. Its shows that management policies are needed.

In relation to the next stage of the study, are first is to encourage a higher level of achievement, comprehensive management policies need to be built so that there is uniformity in application and achievements in each unit. Second, this study concludes that sustainability is based on the principles and criteria of sustainable palm oil for the benefit of consumer products, for the future sustainable palm oil depends on the integration of standards set depending on which segment the product will be traded for. In the next stage management needs to integrate the application of standards to ensure that the products produced can meet market demand. Third, the application of sustainable development in sustainable palm oil development is also linked to government policy. Government needs to provide encouragement and incentives to all industry players both companies and independent smallholders to implement sustainable palm oil standards in their production activities.

\section{ACKNOWLEDGEMENTS}

We would like to thank the Management Perkebunan Nusantara V, Pekanbaru Riau Province and the Postgraduate Program of Environmental Science, University of Riau for all facilities provided during collecting and analyzing data and writing reports.

\section{REFERENCES}

[1] Diesendorf, M. (2000). Sustainability and sustainable development in Dunphy. D, Benveniste, J, Griffiths, A and Sutton, P (eds) Sustainability: The corporate challenge of the 21st century, Sydney: Allen and Unwin, chap. 2, 19-37.

[2] Shamsul, H.M. (2000). Environmental discourse and sustainable development. Ethics and the Environment 5(1): 3-21. $\quad$ http://doi.org/10.1016/s10856633(99)00034-0

[3] Round Table on Sustainable Palm Oil, Occupational Safety and Health Management System National Interpretation of the 2013: RSPO Principles and Criteria for Indonesia. Indonesian National Interpretation Task Force,

2016. https://rspo.org/public_consultations/download/fa60822 9dcfda61.

[4] Panjaitan, M., Syahrin, A., Suhaidi, Siregar, M. (2014). Legal analysis of ISPO (Indonesian sustainable palm oil) certification obligations in relation to investment growth in Indonesia (study at rea Kaltim plantation Ltd - Jakarta). USU Law Journal, 2(2): 43-61. https://www.neliti.com/publications/14213/analisishukum-terhadap-kewajiban-sertifikasi-ispo-indonesiansustainable-palm-o.

[5] Ministry of Agriculture, Joint Study of the Similarities and Differences of the ISPO and RSPO Certification Systems Secretariat of the Indonesian Commission on Sustainable Palm Oil (ISPO). Jakarta, 2015. https://rspo.org/articles/download/e002338a5f874f1

[6] Regulation of the Minister of Agriculture of the Republic of Indonesia Number 11/Permentan/Ot.140/3/2015: About the Indonesian Sustainable Palm Oil Certification System (Indonesian Sustainable Palm Oil Certification System /ISPO).

[7] Round Table on Sustainable Palm Oil (2013). RSPO Certifications Systems for Principles and Criteria, Endorsed by the RSPO Board of Governors on 14th of June 2017.2 https://rspo.org/keydocuments/certification/rspo-certification-systems.

[8] Rusli, A., Sitorus, S.R.P., Fauzi, A.M., Widiatmaka, W. (2016). Achievement of Indonesian Sustainable Palm Oil (ISPO) standards in managing palm oil plantations in East Kalimantan. Journal of Biology, Agriculture and Healthcare, 4.

[9] Fuadah, D.T., Ernah. (2018). Management of oil palm plantations based on principles at PTPN VIII Cikasungka, Jawa Barat. Jurnal Ilmu Pertanian Indonesia (JIPI), 23(3): 190-195. http://doi.org/10.18343/jipi.23.3.190

[10] Suprapto, S., Awang, S. A., Maryudi, A., Wardhana, W. (2018). Actor contestation in the process of revising the Provincial Spatial Plan (RTRWP) in Indonesia (Case Study: Revised RTRW of Riau Province). Regional and Environmental Journal, 6(3): 193-214. http://dx.doi.org/10.14710/jwl.6.3.193-214

[11] GAPKI, 2016 Palm Oil Industry Reflections and 2017. Projection. Press Releases, uploaded dari https://gapki.id/refleksi-industri-kelapa-sawit-2016prospek-2017/. 2017.

[12] Nurjannah, S., Amzu, E., Sunkar, A. (2016). The role of high conservation value areas for the conservation of biodiversity in Riau province oil palm plantation. Minutes of Agricultural and Environmental Policy, 3(1): 68-77. http://dx.doi.org/10.20957/jkebijakan.v3i1.15237

[13] Orhan, G., Erdoğan, D., Durmaz, V. (2015). Adopting mission and vision statements by employees: The case of TAV airports. Procedia - Social and Behavioral Sciences, 150: 251-262. http://dx.doi.org/10.1016/j.sbspro.2014.09.051

[14] Walker, S.M., McMurray, A., Rinaldy, F., Brown, K. and Karsiwulan, D. (2018). Compilation of Best 
Management Practices to Reduce Total Emissions from Palm Oil Production. Winrock International. Report to Roundtable on Sustainable Palm Oil (RSPO). https://rspo.org/publications/download/69cff684739283 a.

[15] Bryson, J.M. (2004). What to do when stakeholders matter. Public Management Review, 6(1): 21-53. http://dx.doi.org/10.1080/14719030410001675722

[16] Donough, C.R., Witt, C., Fairhurst, T. (2009). Yield intensification in oil palm plantations through best management practice. Better Crops, 93(1): 23-27.

[17] Nurindah. (2006). Pengelolaan agroekosistem dalam pengendalian hama. Pengelolaan Agroekosistem dalam Pengendalian Hama (Nurindah), 52(2): 78-85. https://media.neliti.com/media/publications/160021-IDpengelolaan-agroekosistem-dalam-pengenda.pdf.

[18] Round Table on Sustainable Palm Oil, Greenhouse Gas Emissions from Palm Oil Production Literature review and proposals from the RSPO Working Group on Greenhouse Gases Final report, 2009 https://www.rspo.org/files/project/GreenHouse.Gas.Wo rking.Group/GHGWGdraftrecommendations240909.pdf.

[19] PT. Perkebunan Nusantara V. (2018). Measurement of Erosion Intensity in Plant Areas. Riau: PT. Perkebunan Nusantara V.

[20] Decree of the Minister of Health of the Republic of Indonesia Number 1405 of 2002: Concerning Health Requirements for Office and Industrial Work
Environment.

https://www.gbcindonesia.org/download/doc_download /41-kepmenkes-no-1405-tahun-2002.

[21] Ramli, S. (2010). Occupational Safety and Health Management System OHSAS 18001. Jakarta: Dian Rakyat Ltd.

[22] Wahyuni, S., Idrus, M.S., Zain, D., Rahayu, M. (2011). Outsourcing sumberdaya manusia: Tinjauan dari perspektif vendor dan karyawan. Jurnal Aplikasi Manajemen, https://jurnaljam.ub.ac.id/index.php/jam/article/view/27 7.

[23] Zahara, R.A., Effendi, S.U., Khairani, N. (2017). Compliance Using Personal Protective Equipment (PPE) Judging from the knowledge and behavior at the staff installation and maintenance of hospital infrastructure (IPSRS). Aisyah: Journal of Health Sciences, 2(2): 153158. http://dx.doi.org/10.30604/jika.v2i2.60

[24] Agustina, D., Hariyadi, Saharudin. (2014). Socioeconomic environmental analysis of sustainable palm oil plantation management based on ISPO criteria in PT. Tapian Nadenggan. Journal of Natural Resources and Environmental Management, 4(1): 43-48. http://doi.org/10.19081/jpsl.2014.4.1.43

[25] Iqbal, M. (2007). Analysis of the role of stakeholders and their implementation in agricultural development. Agricultural Research and Development Journal, 26(3): 89-99. 